Crete: Its Scenery and Natural Features: Discussion

Author(s): Arthur Evans and J. L. Myres

Source: The Geographical Journal, Vol. 54, No. 3 (Sep., 1919), pp. 153-157

Published by: geographicalj

Stable URL: http://www.jstor.org/stable/1780055

Accessed: 20-06-2016 08:24 UTC

Your use of the JSTOR archive indicates your acceptance of the Terms \& Conditions of Use, available at

http://about.jstor.org/terms

JSTOR is a not-for-profit service that helps scholars, researchers, and students discover, use, and build upon a wide range of content in a trusted digital archive. We use information technology and tools to increase productivity and facilitate new forms of scholarship. For more information about JSTOR, please contact support@jstor.org.

The Royal Geographical Society (with the Institute of British Geographers), Wiley are collaborating with JSTOR to digitize, preserve and extend access to The Geographical Journal 
and the Labyrinth will remain the real Minotaur and the real Labyrinth of childhood days, in spite, alas! of proven facts and even of Sir Arthur Evans! And some may well go for scenery alone, and for a certain indescribable charm the island has. As one who has travelled and stayed in many lands, I can say, without going beyond the literal truth, that I do not know any place that can charm one more when one is there, or for so long after one has left can hold one more strongly under the spell of memory, than this most beautiful island of Crete.

\section{Note on transliteration.}

Place-names are so variously spelt and pronounced in Crete (e.g. ' $E \lambda \epsilon \dot{\theta} \theta \epsilon \rho \nu \alpha \iota$, 'E $\lambda \epsilon \dot{\theta} \theta \epsilon \rho \nu a$ or 'E $\mathrm{\lambda} \epsilon \nu \theta \epsilon \rho \nu \alpha)$ that I have usually followed the first spelling as given

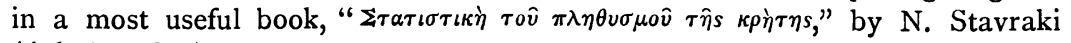
(Athens, I890).

Before the paper the President said: Mr. Trevor-Battye, who is to address us to-night, is a very well-known traveller, naturalist, and author. We have been accustomed lately to interest ourselves in Crete from the point of view of the marvellous discoveries which have been made there by Sir Arthur Evans and others, but to-night we are to have a description of Crete from the purely picturesque point of view, by Mr. Trevor-Battye, who of all men is perhaps best able to give us an account of Crete from that point of view.

\section{Mr. Trevor-Battye then read the paper printed above, and a discussion followed.}

After the paper the PRESIDENT said : We have a distinguished visitor here to-night in the person of Sir Arthur Evans. I will ask him to address the meeting.

Sir ARthur Evans: I am very glad to meet my friend, Mr. Trevor-Battye, again and to hear his very interesting and romantic account of the island, which appeals, perhaps, almost more to those personally acquainted with its scenery than even to those who do not know it. I feel that it is a very good thing that you should have this account from Mr. Trevor-Battye, because of all the travellers who have been through Crete in recent times, and there are a good many altogether, none, I think, have done the country more thoroughly, shrinking from no hardships and with the determination to see things through, than Mr. Trevor-Battye. And though he has not said it, he himself has made very important and interesting contributions to the natural history of the island. He only mentioned one-the shrew. I know there was a great deal more. I remember the interest he took in what I might call at the time the pet of our excavations at Knossos, which happened to be a squeaking beetle.

We have heard a great deal of the interior geography of Crete illustrated in a most beautiful manner. I would only ask you just for a few moments to look at Crete as it stands, as it has always stood, as Homer saw it and as we see it to-day, as the great central island of the Eastern Mediterranean, and there you will find its whole history, and a good deal even of the history of our continent, contained in a nutshell. Crete is a half-way house between the three continents. It stands, as you know, in one direction within hail of Greece. On clear days from the heights about Knossos the peak of Melos is distinctly visible. On the other side, Karpathos and Rhodes are stepping-stones to the shores of Asia Minor. But what is in some ways more interesting, it is also within easy range 
of the African shore ; its southernmost haven is, in fact, only about 180 miles distant from Derna, a port of Cyrenaica. Moreover, the two great prevailing winds, the south-east and north-west, which continue during certain months of the year, make those communications across the Libyan sea still more easy, while on the other hand there are Mediterranean currents which facilitate these communications. The result is that, although the earliest history of Crete, and certainly the geological history, is connected with Asia Minor and Greece, although we know that it once has formed part of a continuous strip of land which shut in the Egean basin, and although the earliest human occupants of Crete seem on the whole to have been nearest akin to the early Armenoid race that inhabited a large part of Asia Minor, still when you get back to the very beginning of insular civilization you find an extraordinary connection with the Nile valley, a connection which goes back beyond the earliest Dynasty and which is so very noticeable even at the dawn of the Cretan civilization, that I can only imagine that some fraction of the pre-historic inhabitants of Egypt actually tcok refuge in Crete at the time of the conquest by the Dynastic race. That may seem an extreme statement, but the phenomena revealed by the recent excavations seem to leave no other conclusion possible. All through the succeeding periods of Minoan culture, moreover, there is evidence of continuous contact with Egypt-with the 4th and 5th Dynasties, with the period between the 6 th and $I I t h$, and in an especial way with the 12 th and again with the 18 th. The special interest of this is that it links on what is the earliest civilization of Europe for the first time in a direct way with the earliest civilization of the Nile valley.

I cannot now enlarge on geographical details, but the one central point about Crete, as Mr. Trevor-Battye has said, is the fact that along the whole length of the island-with one little break-runs a great mountain backbone. And this physical condition accounts for a curious fact in Cretan history. I am well acquainted with Crete, and I am fairly well acquainted with another even more historic island, Sicily; and there are some very remarkable contrasts observable to be accounted for by this special peculiarity of Crete. Both countries were conquered by the Saracens; both were for centuries under Arab rule. In Sicily, of course, as many of you know, you find through the whole interior place-name after place-name, even the most remote villages and rocks, still retaining a reminiscence of their Arab names from "Mongibello "onwards. When you go into the interior of Crete, on the other hand, in spite of its historic subjection to Saracen dominion, you can hardly find a single trace of Arab names. What you do find is that along many parts of the coast there are no villages. The larger villages, as a rule, still cling to the interior and stand away from the coast. Their inhabitants shrank away from the maritime tract dominated by the Arab corsairs ; they clung to the interior. Crete has thus concentrated its indigenous forces in the inner glens of the country. Though in later days Crete was nominally a Turkish province, its mountain backbone still provided a refuge for recalcitant spirits. There have been over one hundred insurrections in all, and though temporarily quelled, a passive resistance was still able to prolong itself in mountain citadels like that of Sphakià. Although nominally the island has been subdued, it has never surrendered itself, and it is this central mountain chain which has enabled the island to hold out. Crete stands before us to-day as a monument of two great causes-the cause of civilization at a time when Europe was still covered with primitive darkness, and the cause of freedom which here at any rate "though often lost was always won," and the full guerdon of which has at last been gained. 
The PRrSIDEnT : Prof. Myres is an old friend of the Society. He was once Chairman of our Research Committee. More lately, I am told, he has been engaged in piratical exploits in the Mediterranean, which involved some doubtful transactions in cattle. Perhaps he will kindly address the meeting.

Prof. J. L. MYRES : I am not going to talk about the Minotaur, but I should like to express what I am sure we all feel, particularly those who know the island, our delight at the description which Mr. Trevor-Battye has given us of this most beautiful piece of the Greek world, and the illustrations which he has thrown upon the screen. I suppose there are very few parts of the Nearer East where it is easier to study the construction of a mountain region. All the processes of mountain-building are not only seen in their results, but one feels in Crete that one is really inside the machine, watching the processes going on. The lecturer has referred to raised beaches round the coast, even at considerable heights above the sea. He might have added that since classical times the whole island has swung upon an axis, the eastern half sinking, the western half rising, so that whereas at Hierapetras and Spinalonga the ancient quays and harbcur works are now under water, the little Greek harbour of Phalasarna, at the west end of the island, is now totally upheaved. You see the quay walls round you on all sides, and can walk about on the floor of the classical and historic harbour, upraised and dry. In the same fashion he has illustrated in the slides and also in the description he has given us, a number of phases of the sculpture, by natural forces, of a mountain range thus upheaved. He has discussed those very curious inland plains, characteristic of all the three Cretan mountain masses. I am inclined to think, from what I have seen of them, that in all probability they are only very well-marked and perhaps rather recent examples of a type of faulted mountain-structure which persistently confronts one all through the Balkan and Ægean region. The Ægean region itself is a piece of the great Alpine and Anatolian folded-mountain region which has broken across and then fallen in, so that instead of lofty mountain chains with highland plateaux between them, we have chains of islands, just the mountainpeaks, emerging above the present sea-level, while the large flat lowlands are submerged and out of human occupation. In the same fashion in Arcadia, in Central Greece, in Macedonia, and right away into Serbia, one passes through one after another of these enclosed faulted valleys; and so I incline to think it is on a smaller scale, but no less distinctly, in these Cretan uplands, let down between great rock-walls, sometimes only on two sides, sometimes on three or four. That helps to account for the circumstance that these enclosed valleys are so frequently dry ; though they are not all dry, and, as we know, there is a regular lake region on the frontier between Greece and Serbia. Another example, which repeats some of the phenomena of the Kurnas Lake in Crete, is the North-Arcadian lake basin of Phonia, the ancient Stymphalos. The rise and fall of level of Phonia are not at all so regular as those reported at Kurnas, but on several occasions the level of Phonia has been suddenly and decisively altered, and in all probability there is some siphon-action in both cases. After a period of extreme rise in the lake-level, once the top of the siphon is reached, the water will run off and may perhaps continue to do so until even the drainage-opening in the lake is exposed. And not only does one find these cavernous drainage-systems associated with existing valleys, but, as Mr. TrevorBattye knows, there are katavothra also down in the lowlands. There is, for example, in Crete the big cave called Skotino, which simply opens with a great hole nearly on the top of a rolling moorland. There is here no drainage area now. Yet once upon a time there must have been a considerable quantity of 
water passing to create this great cav', as large as the nave of a cathedral. Further, in those mountain-basins themselves traces of deposits bear out the view that from time to time, at all events, they have been filled with water, the katavothron being temporarily blocked and then re-opened under excessive water-pressure. I know one such mountain-plain, at Flammarí in Samos, where the natives do the blocking themselves. That plain is literally converted into a little Egypt annually. When the winter rain is due, the people block the katavothron and mark its place with poles. Then the winter rain comes on and floods the whole plain, and after a time they dislodge the stones and let the water off.

That is only one instance of the kind of geological observation which one is constantly called upon to make in Crete. The same may be said with regard to snow action. The snow drifts on the upper parts of Mount Ida, and in my experience it lasts right round the year. In 1893 I saw the north side of Mount Ida with a good deal of snow on it as late as the end of August. Those snow.drifts are, of course, the last remnant of a snowcap which in earlier and severer conditions are responsible, in all probability, for those enormous accumulations of the red gravel to which Mr. Trevor-Battye has referred. It was extremely interesting to me to hear that he thinks he has identified actual iceworn stones. I have looked for indications of ice-marking in Crete, but was never able to satisfy myself, "probably because so large a proportion of the boulders are of limestone, which is rather porous and soluble, so that during the long periods in which they have remained in the gravel their surfaces have worn away. It is a very interesting contribution to our knowledge, if ice-worn blocks have been observed in Crete.

These are points which suggest themselves to an old Cretan traveller among the interesting contributions to our knowledge given by the lecturer to-night.

The President : We have listened to-night to a most delightful address, a most graphic description of the physical characteristics of Crete, combined with a sort of blend of old academic mythology which has lent it a very peculiar interest. There is one point in the course of the lecture to which I should like to refer. That curious phenomenon of the submarine and fresh-water springs is not quite so uncommon as most people think. I only know of one particular instance, but it is a very important one. The Bahrein Islands in the Persian Gulf derive their water-supply from a submarine spring of this sort, and it is very curious to see men go off at low tide in the morning in open boats with a tank in the middle of the boat, and then suddenly dive down into the water and place the head of the pipe over the spring in order to carry the fresh water up into the tanks. That is the only water-supply that one of their biggest towns can depend upon. There is another matter which does not absolutely affect Crete itself, but which, I think, may possibly interest you. I do not think it is known to very many people that the mythology which we have all dipped into more or less in our school-days and which still contributes to the romance of Crete, but which is there an absolutely dead letter, should exist as a living faith some 3000 miles from Crete. And I can tell you very shortly how it is so. From Peshawar, if you look northward, you will see three points of a mountain which lies beyond the intervening foothills and which is called the Koh-i-Mor. It is outside our boundary, well within the limits of the independent tribes, and nobody is allowed to visit it. On the southern slopes of that mountain there are the remains of an ancient city called Nicæa. In the maps of the Indian frontier published fifty years ago that name appeared, and in its right place. Lately, however, inasmuch as there is nothing left of that place above gruund, 


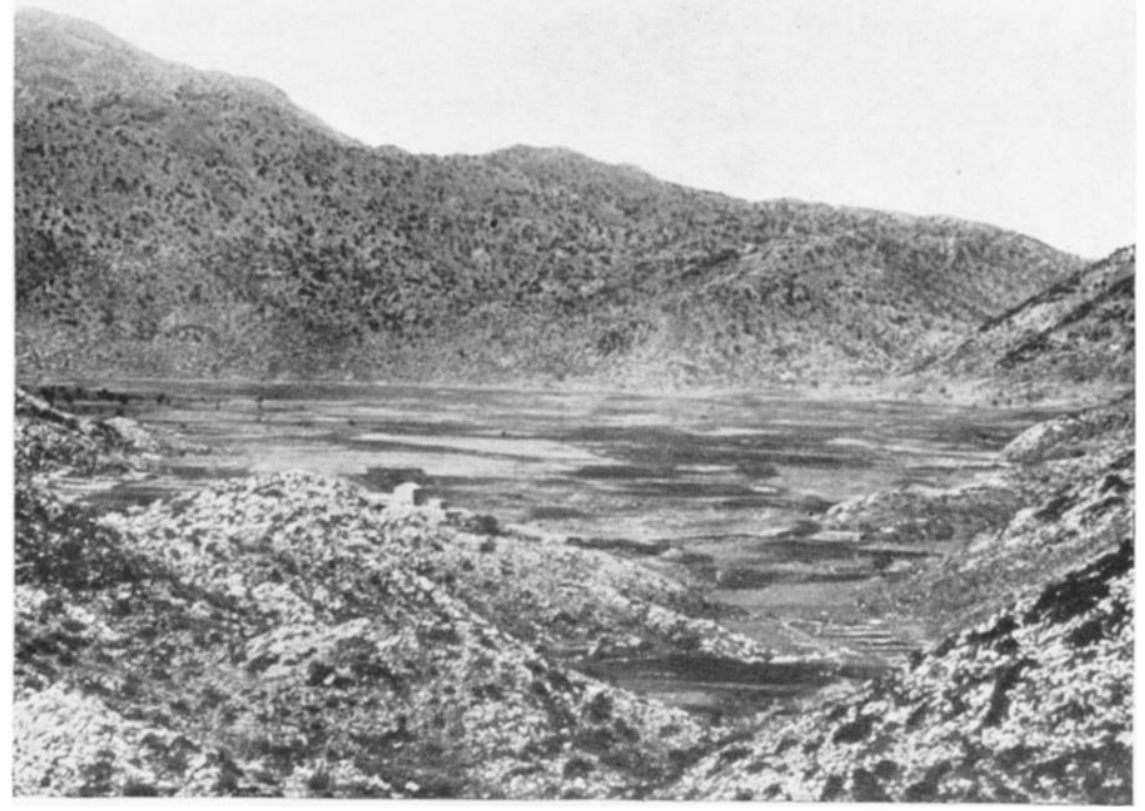

THE MOUNTAIN PLAIN OF HOMALO

Phot. by M. Diamantopoulos

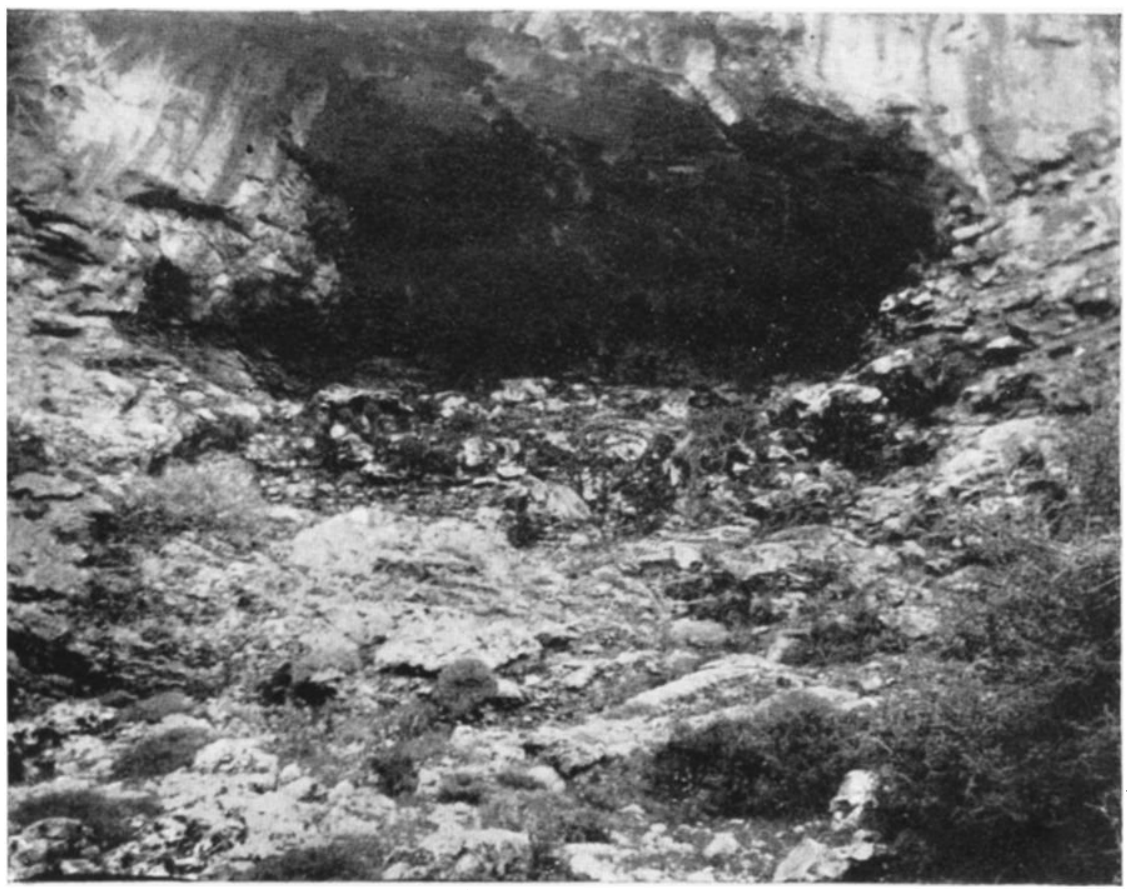

THE KATAVOTHRON OF HOMALO 


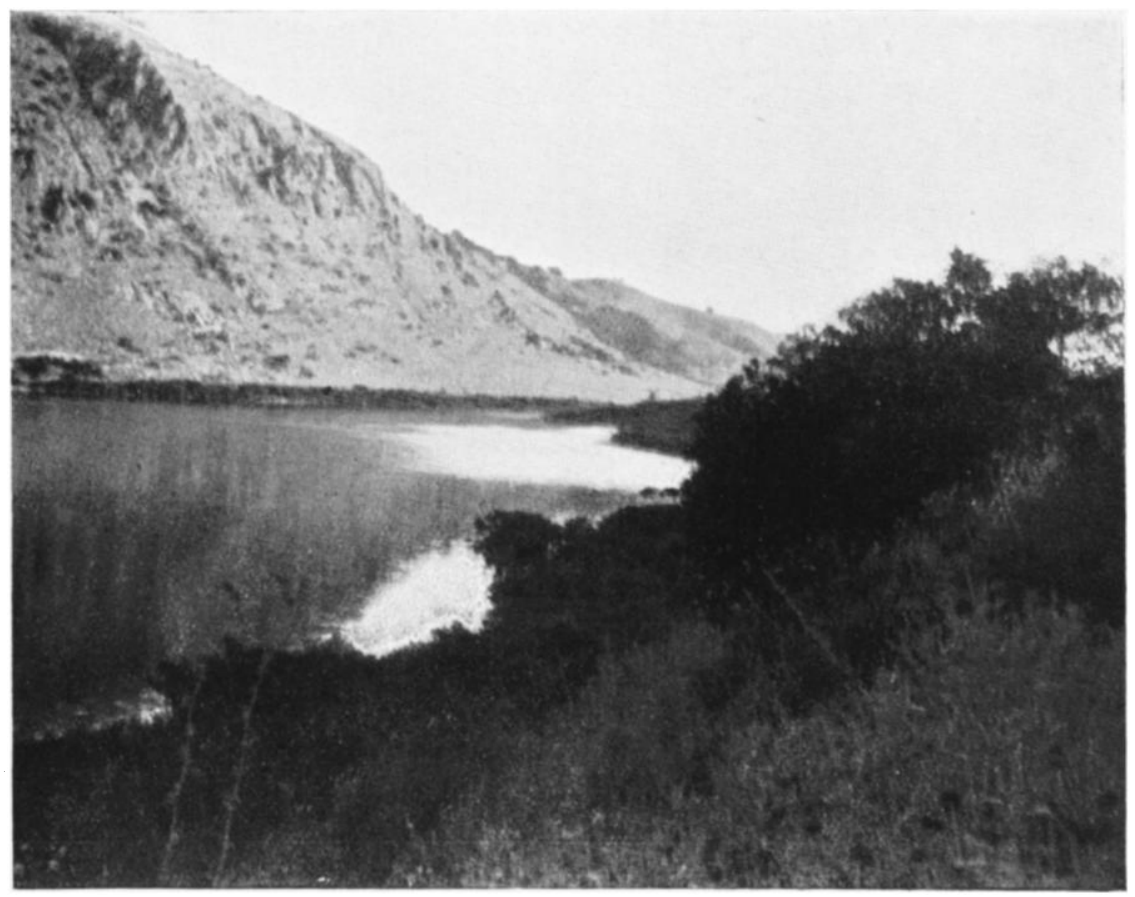

LAKE KURNAS

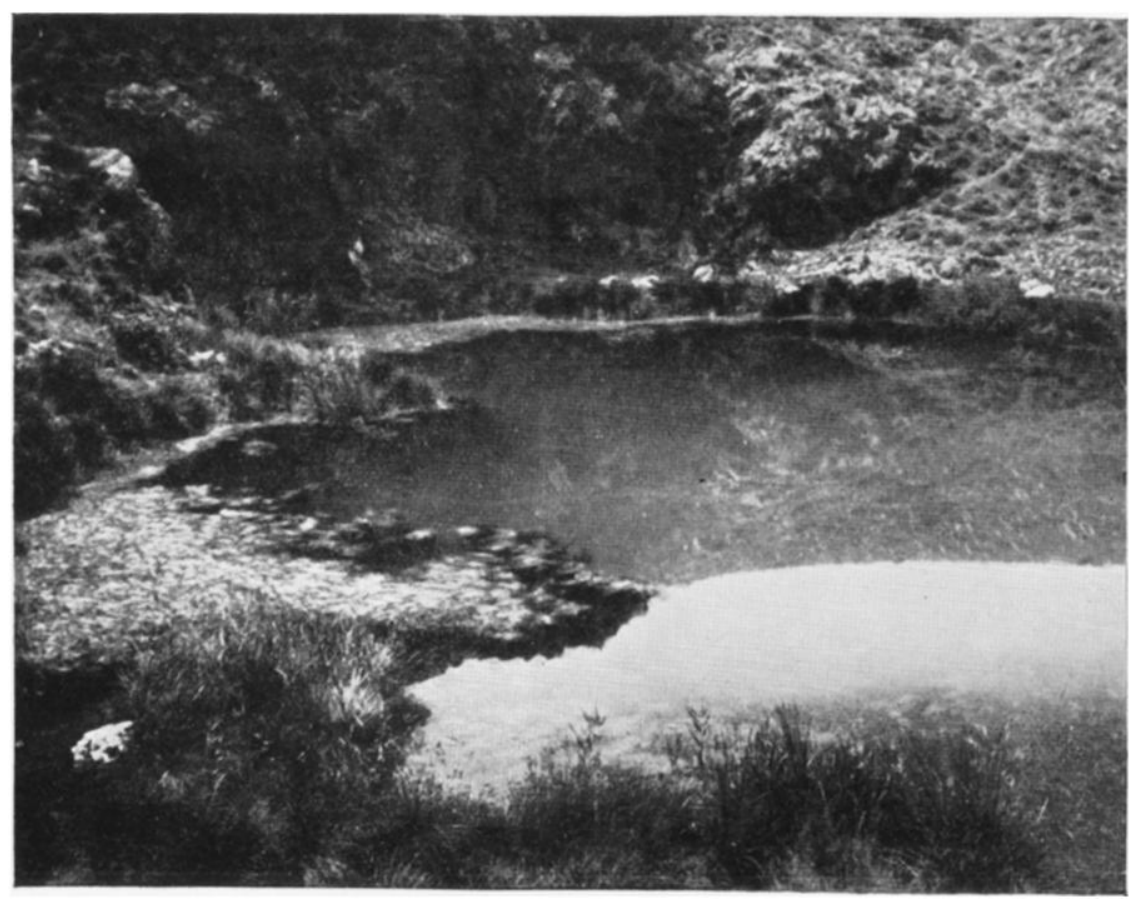

THE HALMYROS OF MALEVIZI

This content downloaded from 128.104.46.196 on Mon, 20 Jun 2016 08:24:42 UTC All use subject to http://about.jstor.org/terms 
the name has disappeared, which I think is a great pity. In tracing out the progress of Alexander's entrance into India from High Asia, one can follow it almost mile by mile as he left the plains of Kabul on his way towards India, until we bring him up, undoubtedly, against this same place Nicæa. Perhaps some of you will remember the story that Arrian tells of how the Nicæans came out to protest against Alexander's destruction of the city, according to his general military method, which was to destroy cities and to efface inhabitants unless he wanted to make use of them. Well, the mountain of Meros is now called by the people there the Koh-i-Mor, which, after all, is indicative of what the ancient name might have been. This might all be treated by anybody reading Arrian's account (written one hundred years after Alexander's death) as a story, possibly, which might well pass, but which has no particular significance now. But as it happens, I found myself twenty-five years ago in the immediate neighbourhood of the Koh-i-Mor. Unluckily, I could not reach it. That is to say, I was on the borders of Kafiristan. The Kafirs occupy all the country west of the river Kunar, pretty nearly as far as Andarab, which is one of the principal valleys of the Baktrian kingdom and full of Greek reminiscences to the present day. But the Nicæans, according to Arrian's account, dated from such a pre-historic period that neither Arrian nor any authority he could quote could find any origin for them at all. Clearly they must have been some centuries there, and they were of Greek or Pelasgic origin, and they have, in my opinion, continuously occupied that country. The people there still claim Greek descent, and the curious fact is that at certain ceremonials, when all the young men get together and have a sort of victory dance, after taking a few Mohammedan heads, they sing songs in honour of their war-god Gish. I was lucky enough to get a copy of the first verse of this song, but I could unfortunately get no more, because the young men are not allowed to sing more than one unless they have taken a certain tale of Mohammedan heads and are reckoned as very special braves. But I got this properly translated, and it is apparently a direct appeal to the god who arose from the "three-horned" peak of the mountain Meros. The god they call Gish has always struck me as possibly the old Greek god Z€us. It would be a matter of immense interest if only we could be sporting and energetic enough to send people into a country which is, after all, not really hostile to us, to investigate the fact more thoroughly and to get the full story from these people.

I think we can do no more now than join in a vote of thanks to Mr. TrevorBattye for his most interesting paper. We have heard a great deal from him and Sir Arthur Evans which is probably new to many of us, and we have had a most enjoyable evening.

\section{THE PARAGUAYAN CHACO AND ITS POSSIBLE FUTURE}

\section{W. Barbrooke Grubb}

\section{Read at the Meeting of the Society, I6 June I9I9.}

THE Paraguayan Chaco forms only a small portion of that great region (even to the present day so little known) called "The

South American Chaco." The Chaco is really a northern continuation 